\title{
$\mathrm{P}-\mathrm{S}$ 時間の頻度分布について
}

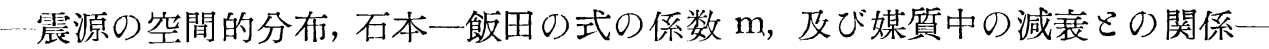

\author{
浅田敏・田望 \\ 東京大学理学部 地球物理学教室 \\ (脽和 29 年: 1 月 9 日受理)
}

\section{On the Frequency Distribution of the P-S Intervals of the Earthquakes Recorded at a Certain Station}

Toshi Asada, and Nozomu Den

Geophysical Institute, Tokyo University

(Received Jan. 9, 1954)

If numbers of near earthquakes are recorded at a certain station during a certain period, the frequency curve of their P-S intervals can be obtained. As the P-S interval of a near earthquake is approximately proportional to its hypocentral distance, it is apt to be considered that the P-S interval frequency distribution stands for the geographical distribution of hypocenters. Of course, it is wrong. In the present paper, the writer pointed out that it is dependent not only on the geographical distribution of the foci, but also on $N(M) d M$ or the magnitude frequency distribution, the decay of the seismic waves, and the response of the seismograph. It is noteworthy that the value of the absorption-coefficient of the earth's crust can be estimated from the data on the P-S interval frequency distribution.

§1. 地震頻発地域で観測を行うと, 地震計の感度及至は其他の理由によつて多少の差異はあ るが，比較的短い時間内に多くの近い地震を記録することが出来る。そのようにして記録され た地震をその P-S 時にしたがつて分類し適当な級間に分けて頻度分布を求めることが行われ て居る。ことに余震観測についてはその例が多い。P-S 時は Omori 係数によつて震源距離 $D$ とむすびつけられて居るので, P-S 時の度数分布はそのまま震源距離の度数分布と見做しても よい。脚声1）そのために值接震源の地理的分布状態を指示するかの様に考えられる傾向がある。 Kawasumi ${ }^{1)}$ は関東地方に発生する地震について簡単なモデルを考え P-S 時の頻度分布と震 度の頻度分布を同時に説明しょうとててろみて居る。しかし，震度の頻度分布については石本

1） P-S 時苍 Omori 係数で震源距晟とむすびつけることには勿論自から制限がある。とのととについ ては, 松沢武雄 萻 地震学, 1950. pp. 171 172 参照。 
飯田の式に於る Matuzawa(2) 又は Suzuki(3) の議論ぶそのまま適用出来るので, 本論文に於て は P-S 時の頻度分布の問題を震度の頻度分布の問題よりきりはなして論じたいと思う。

§2. P-S 時文は $D$ の頻度分布を考察するために最初に次のモデルを考えてみよう。すなわ ち地震は地表面上に一様な密度で発生して居り，且すべての地震はある一定の magnitude 又 は最大復振巾をもって居るとする。ての場合 “振動周期”(4) もすべて同じであると考えてお く。このモデルは Matuzawa が石本一飯田の式の議論をするときに採用したものと同じもの であり，下のように表現出来る。

$$
\left.\begin{array}{l}
f\left(A_{0}\right)=\infty, \quad A_{0}=a \\
f\left(A_{0}\right)=0, \quad A_{0} \neq a \\
\lim _{\varepsilon \rightarrow 0} \int_{A_{0}-\varepsilon}^{A_{0}+\varepsilon} f\left(A_{0}\right) d A_{0}=1
\end{array}\right\},
$$

ここに， $A_{0}$ は夫ょの地震の震源に於る最大振巾， $a$ はある constant, $f\left(A_{0}\right)$ は $A_{0}$ の分布 を表す。この様な場合にこの地震群を地表面上のある一点で観測すると P-S 時の頻度分布は Fig. 1 のようになるてとは明らかである。すなわち， $\triangle 0 A B$ のような直角三角形になる。地 震波は $D$ とともに減垶するから $\mathrm{P}-\mathrm{S}>\overline{O B}$ の範囲にある地震は観測され ない。距離 $\overline{O B}$ は $a$, 地震計の倍率及媒質中の減窔の程度によつて定ま る。一定時間に観測される地震の総数は $\triangle 0 A B$ の面積によつて表わされ

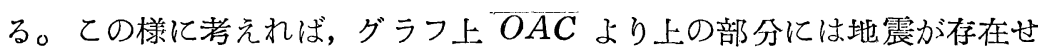
ず，CAB より右の部分には地震は存在するが，観測不能であるてと汸わ かる。

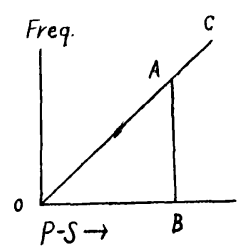

Fig. 1

しかし，最大振巾に関して上述の分布密度を持つ様な群発地域は実際には未だ発見されて居 ない。実在の頻発地帯ではその成立の範囲等について多少の問題(5)を含むとしても, magnitude 又は $A_{0}$ について

$$
\left.\begin{array}{l}
N(M) d M=\text { const. } \times 10^{-b M} d M \\
N\left(A_{0}\right) d A_{0}=\text { const. } \times A_{0}{ }^{-m} d A_{0}
\end{array}\right\},
$$

の型の度数分布がなりたつて居る様である。一方，観測点での最大変位振巾を $A$ とすると，

$$
N(A) d A=\text { const. } \times A^{-m} d A,
$$

のような同じ型の式がなりたつて居るととが経験されている。

この様な事実を考えに入れて実際に得られる P-S 時度数分布考考えてみよう。

観測された地震の総数は，頻度分布を示す曲線と横軸の間の面積であらわされるととは前述 の場合と同じである。地震のかずをかぞえる時に夫くの地震の観測点での最大振巾 $A$ は考慮に 
入らないから,ての面積内で 1 ケの地震は夫ณの $A$ にかかわらず一定の面積をしめることにな つて店る。然し P-S 時の夫«の級間について $A$ の大きい地震程てのグラフ上で, 下の方に, すなわち，横軸に近い所におくとすると P-S 時の度数分布曲線は観測不能と可能の地震の境 界を示すととになる。すなわち，曲線と横軸でかてまれた部分内に観測可能の地震があり，そ の外側すなわち上側には観測不能の地震が位置をしめる。

この様に考えてみると, P-S 時又は $D$ の度数分布曲線のかたちは震源の地理学的な分布状 態のみならず， $M$ 又は $A_{0}$ の頻度分布，及び地震波ぶ $D$ とともに減埰する仕方によるととが わかる。更に地震動の “卓越周期” は $D$ 及振币に関係するから, さきの $\mathrm{P}-\mathrm{S}$ 時頻度分布曲 線のかたちは地震計の周波数特性によつて影響されるであろうことも容易に考えられる。

同じ場所で地震を同時に観測しても，変位記象を用いて P-S 時頻度分布を作っつた結果と 加速度計により得られた P-S 時頻度分布とはお互に異る筈である。变位計による結果と有感 地祳の P-S 時頻度分布, すなわち人体感覚による統計結果とは後述の如く異つて居る。

特性が等しく感度の異る地震計で観測した時, Fig. 1 亿示される場合に於ては感度の高低に 従っで境界 $A B$ が右及左に動くことになる。第二の場合には各級間につき観測される地祳の 個数は夫及同じ制合で増減する。従って，特性の等しく倍率のてとなる地震計によつて同時観 測をするてこによつて地震の群発の仕方の統計的な性質を推測するてとが出来る。

§3. 前章の考察を定量的にとりあつからために先づ最も簡単なモデルを採用してみよう。 地表面に一様な密度で地震が発生して居る場合，それをある一点で観測した時に得られる $\mathrm{P}-\mathrm{S}$ 時頻度分布を考えてみることにする。今記録紙上の最大振巾を $A$, その城震の震源に於 る最大振巾を $A_{0}$ と書く。

観測点より $\Delta, \Delta+d \Delta$ の間に位置し，その振巾は $A_{0}, A_{0}+d A_{0}$ の間にある地震の数を

$$
N_{0}\left(A_{0}, \Delta\right) d A_{0} d \Delta
$$

とすると，

$$
N_{0}\left(A_{0}, \Delta\right) d A_{0} d \Delta=2 \pi \Delta \rho\left(A_{0}\right) d A_{0} d \Delta
$$

ここに $\rho\left(A_{0}\right)$ は unit area に於る $A_{0}$ に関する頻度分布を示す。地震学に於て知られて居 る事実より，

$$
\rho\left(A_{0}\right)=k A_{0}^{-m},
$$

とおく。しからば，

$$
N_{0}\left(A_{0}, \Delta\right) d A_{0} d \Delta=2 \pi \Delta k A_{0}{ }^{-\mathrm{m}} d A_{0} d \Delta,
$$

ここに $k$ 及 $m$ は夫ヶ constant である。所で地震波は伝播距離とともに減衰するから，そ の観測点で観測し得る最小の地震の夫火の震源に於る振巾 $A_{0}$ は夫«の $\Delta$ が大きくなるにつ 


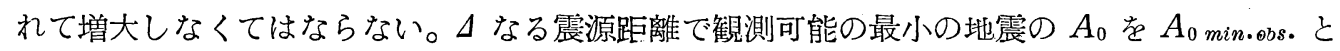
書くと,

$$
A_{\text {omin. øbs. }}=a(\Delta),
$$

のように のの函数として表わされる。メ一方地震計について記録し得る最小の地震の記録紙上

の振巾を $A_{\min }$. とかくと，

$$
A_{\text {min. }}=\alpha,
$$

$\alpha$ は一怘 constant として考えてよく,脚註2) 記録装置の解析力，観測地に特有の background noise のありさま，地震計の倍率によつて定められる。しかるとき，

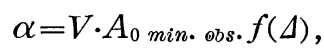

こてに $V$ は倍率, $f(\Delta)$ は $\Delta$ にるる地震動の, 振巾の減㐮の型式を示す。すなわち,

$$
A=A_{0} \cdot V \cdot f(\Delta) \text {. }
$$

したがって，

$$
a(\Delta)=\alpha / V \cdot f(\Delta) .
$$

今, 問題の観測点で観測し得る地震の内, $\Delta, \Delta+d \Delta$, の間に位置するものの数を $N(\Delta) d \Delta$ と すると，

$$
N(\Delta) d \Delta=\int_{a(\Delta)}^{b(\Delta)} 2 \pi \Delta k A_{0}{ }^{-m} d A_{0} d \Delta
$$

$b(\Delta)$ は考え方により色々にとれるが事実上は $\infty$ とおいても大した差は生じない。しかるとき，

$$
N(\Delta) d \Delta=\frac{2 \pi k}{m-1} \cdot \Delta \cdot a(\Delta)^{1-m} d \Delta .
$$

メは，

$$
N(\Delta) d \Delta=\frac{2 \pi k \alpha^{1-m}}{m-1}, V^{m-1} \cdot \Delta \cdot f(\Delta)^{m-1} d \Delta
$$

すなわち，上の様なモデルを考えた時，その P-S 時頻度分布の型は，減䒾の型式及地震の $A_{0}$ の頻度分布の型により定められ，又一方観測される坜震総数は倍率と $A_{0}$ 頻度分布によつて定 められることが分る。 $A_{0}$ の頻度分布が石本一飯田の式の型をもつて居る場合, 観測される地 震の数は $V^{m-1}$ に比例することも一応注意すべきであろう。このととは勿論, 石本一飯田の式 から容易に直接みちびくことも出来る。

§4. 此の地震頻発面が地下 $h$ なる位置にあつたとする。この場合の $\mathrm{P}-\mathrm{S}$ 時頻度分布を求め るには前章と同じ考えで求める式について, $\Delta^{2}+h^{2}=D^{2}$,

2）特有の spectrum をもつ background noise の上に，地震動の小振巾の記象がかさなつて記録され て居る場合には，後者の spectrum はその $D$ によつて，たとえば P-S 時 $2 \sim 3$ 秒位の場合と 20 30 秒の場合によつてかなり異なるから， $\alpha$ はかならずしも constant とは云えないとともある。つ まりある P-S 時の記象が見のがされやすい傾向の生する場合もある。 
なる関係を考え, 変数 $\Delta$ を $D$ 亿変換すればよい。すなわち,

メは,

$$
\begin{aligned}
& N(\Delta) d \Delta=\frac{2 \pi k \alpha^{1-m}}{m-1} V^{m-1} \cdot \Delta \cdot f(\Delta)^{m-1} d \Delta, \\
& N(D) d D=\frac{2 \pi k \alpha^{1-m}}{m-1} V^{m-1} \cdot \Delta \cdot f(D)^{m-1} d \Delta d D, \\
& N(D) d D=\frac{2 \pi k \alpha^{1-m}}{m-1} V^{m-1} \cdot D \cdot f(D)^{m-1} d D .
\end{aligned}
$$

上の如く，さきの場合と同じ型になるととが分る。ただし， $D \leq h$ の場合には，

$$
N(D) d D=0
$$

§5. モデルをより実際的にするために厚さを有する層の例を考えるてとにする。層は深さ $H_{1}$ より $H_{2}$ にわたり, その内で地震は一様な密度で発生して居るとする。ての様なモデルは $M_{K}$ 又は $A_{0}$ の頻度分布に関する点を除いては Kawasumi(7) の採用したモデルと同一である。

厚さのある層の場合の $\mathrm{P}-\mathrm{S}$ 時頻度を, $N_{h}(D) d D$ と書くことにする。しかるとき，

$$
\begin{aligned}
& D \leq H_{1}, \quad N_{h}(D) d D=0, \\
& H_{1}<D<H_{2}, \quad N_{h}(D) d D=N(D) d D \int_{H_{1}}^{D} d h \\
& =N(D)\left(D-H_{1}\right) d D \text {, } \\
& H_{2} \leq D, \quad N_{h}(D) d D=N(D) d D \int_{H_{1}}^{H_{2}} d h \\
& =N(D)\left(H_{2}-H_{1}\right) d D,
\end{aligned}
$$

のような結果を得る。なほ，ての場合は， $\rho\left(A_{0}\right)=k A_{0}-m$ に於る $k$ の dimension は前の場合 と異る。いづれにしても $N(\Delta) d \Delta, N(D) d D, N_{h}(D) d D$, はすべて dimension のない数であ るから, 夫くの場合について constant の dimension はかわつてくる。

なほ此の式は polar-coordinates 定用いて層の境界として，

$$
D \cos \theta=H_{1}, \quad D \cos \theta=H_{2}
$$

と置き $\$ 3$ と同じ考え方で求めることも出来る。又は，ある半径 $D$ なる球面を，おたがの 距離が $h$ である平行二平面で切つた場合その切り口で出来る帯の表面積は， $2 \pi D h$ であるとと を考えれば，上述の答の得られること注自づから明らかであろう。

§6, 実在の地震頻発地域はすべて有限の拡りをもつて居り, Хかならずしもその拡りの内部 で一様に発生して居るわけではない。しかし, 第一近似として 5 の如きモデル，すなわち地 震は深さ $H_{1}$ 及 $H_{2}$ なる二平面のあいだで一様な密度で発生して居ると考えてもよいと思われ 


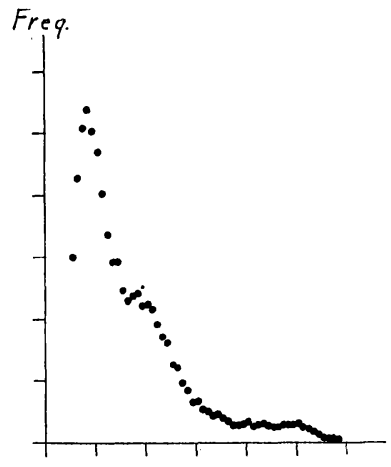

Fig. 2 a

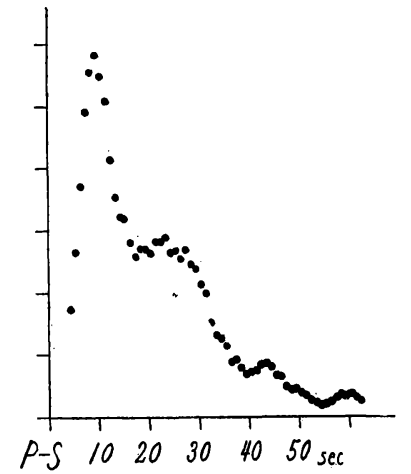

Fig. $2 \mathrm{~b}$

Frequency distribution of the $\mathrm{P}-\mathrm{S}$ intervals of shocks recorded by a displacement seismograph: a, at Hongo, Tokyo; and b, at Mitaka. The curves are smoothed by the arithmetic-moving-average-method.

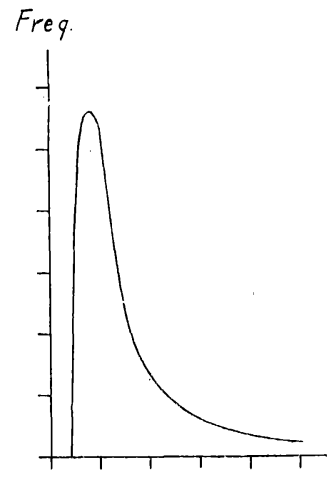

Fig. 3 a

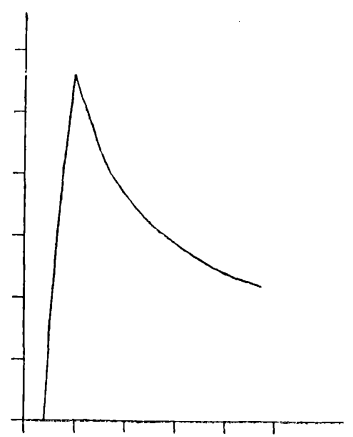

Fig. 3 c

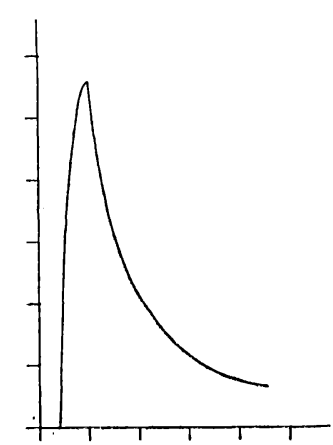

Fig. $4: b$

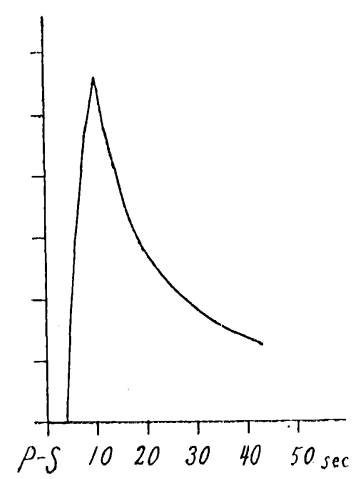

Fig. $3 \mathrm{~d}$

Frequency distribution of P-S intervals calculated according to the formula in $\S 5$.
a : $m=2, \quad f(D) \propto 1 / D^{3}$,
b : $m=1.8, \quad f(D) \propto 1 / D^{3}$,
c : $\quad m=1.8, \quad f(D) \propto] / D^{2}$,
$\mathrm{d}: \quad m=2, \quad f(D) \infty 1 / D^{2}$. 
る場合もある。との一例としては関東地方一冈に発生する地震を東京で観測する場合等をとり あげるととが出来る。

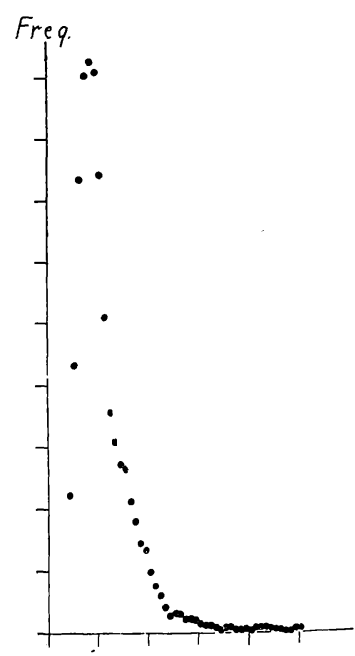

Fig. 4 a

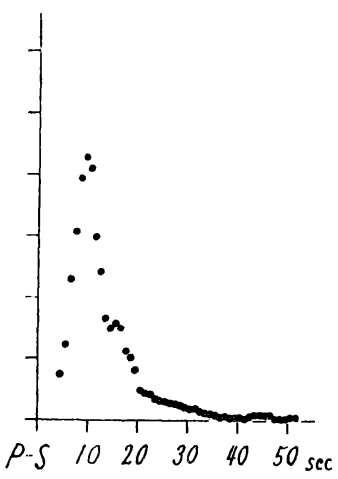

Fig. 4 b

Frequency distribution of the $\mathrm{S}-\mathrm{P}$ intervals of sensible earthquakes occurring during the period of 1924 and 1937.

a: Hongo, Tokyo,

b: Mitaka.

The curves are smoothed.

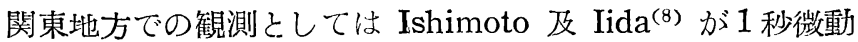
計を用いて 1936-1939 の間に行つたものがある。彼等の観測で 得られた本郷及三鷹での P-S 時頻度分布を Fig. 2 に示す。と れは移動平均をとり滑らかにしてある。

この 2 例に対応するものとして， $H_{1}=4 \mathrm{sec}, H_{2}=10 \mathrm{sec}$ ，な るモデルを考えてみる。すなわち，Omori 係数を 7 とすれば $28 \mathrm{~km}$ より $70 \mathrm{~km}$ にわたるあつさ $42 \mathrm{~km}$ の層を地震頻発層と

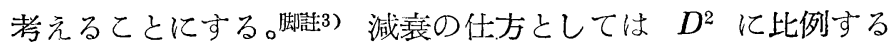
場合及 $D^{3}$ に比例する場合をとり，夫ぬ $m=2$ 及 $m=1.8$ の場 合につき計算したものを Fig. 3 に示す。

関東地方の地震にての様なモデルをあてはめる場合，計算さ れた頻度分布と穾際の P-S 時頻度分布とをあまり立入つて, 比 較論議することは不適当であるが，Fig. 2 及 3 を参照すれば P-S 時に関する前述の考え方が大体に於て正しいと考えてよい 事少汾る。脚詩4)

更に実際の観測の例として震研観測報告より 1924-1937 の間 の東京に於る有感地震を基として作られた P-S 時頻度分布に 注目して見る。Fig. $4 \mathrm{a}$ 及 b はしの頻度分布に移動平均を行つ て平滑にしたものである。1 秒微動計による結果である Fig. 2 々くらべると，同じ地域に発生する地震をほぼ同じ期間に観測 して居るにもかかわらずそのかたちが異つて居る事に気がー <。

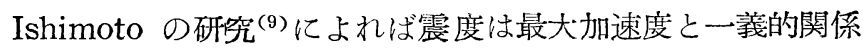
がある。したがつて, Fig. 4 亿示した P-S 時頻度分布は $10 \mathrm{cps}$ の “加速度計” の観測による統計結果と等しいと考えてよい。

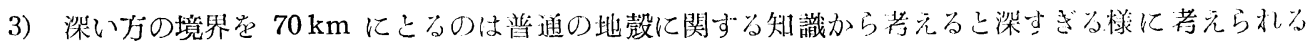

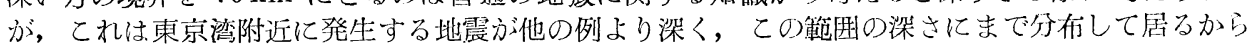
である。

4) 余震観湘等に於る P-S 時分布の実例を参照すると 5 記載の式と同じかたちのものが多くみられる 様である。余震観測の多くは発震地域の直上で行われるために 85 亿於る様なモデルが近似的にな りたつが場合多いのであろう。 
一方 1 秒微動計は記録されて居る地震が

規模の小さいものであるてと，又ほぼ $D \leq 200 \mathrm{~km}$ の範囲に属するものである ことを考えると $P$ 及 $S$ 相では変位計と して動作すると考えてよい。従って Fig. 2 及 Fig. 4 の相違は変位計と加速度計に よる観測の差違と考えることが出来る。

上述の P-S 時頻度分布の差異を説明 するためには，ての様に特性のことなる 地震計で観測した場合，Fig. 2 及 4 の 如き差を生じる殔に地震動の spectrum が $D$ とともに変つて居ると考えるのが おんとうであうう。すなわち，ての事柄 は地震動の変位振巾より最大加速度の方 が $D$ につれてよりはやく減釙するとと

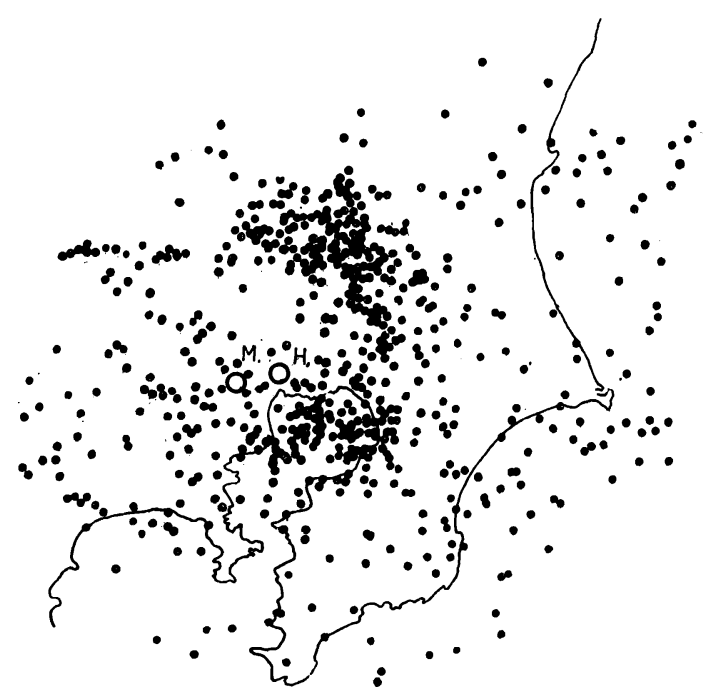

Fig. 5 The epicenters of the shocks occuring during the period of 1924 and 1940 .

$\mathrm{H}$ : Hongo, Tokyo, M : Mitaka.

を示して居り, 爻は“卓越周期”が $D$ とともに大になる傾向にある事を意味して居ると考えら れる。又一方最大加速度 $\alpha$ について頻度分布をつくるとやはり石本一飯田の式些得るのである が, この場合 $m$ が最大振巾に対する場合より大になるととも考光に入れなくてはならない。(10) いづれにしても同一の点で観測しても，P-S 時頻度分布については，地震計の特性によりて となつた結果を得る事は興味あるてとがらであって，ての事実を用いて，一点観測によって地 款中の“viscosity”等に関する研究をすすめるてとが可能であることを示して居る。

ての問題についてはヌ別の論文でとりあげたいと思う。

なほ Fig. 5 は参考のために震研観測報告記載の震央を, 1924 より 1940 までのものにつき plot したものである。松沢先生の御指導を感謝する。
1) 河 角広：震研彙報 30 (1952) p. 325
2) 松 沢 武 雄: 震研黄報 19 (1941) p. 411
3) 鈴 木 次 郎：地震学会講演 1948 年 10 月
4) 浅 田 敏：地震 6 (1953) p. 1
5) 浅 田敏：地震 7 (1954) p. 21
6) (4) と同じ
7) (1) と同じ
8）石本已四雄, 飯时 可：震研策報 $\mathbf{1 7}$ (1939) p. 443

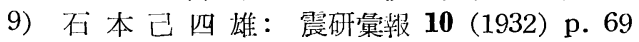
10）浅 田 敏：地震 6 (1953) p. 69 